\title{
Effect of Rice Bran and Leucaena Supplementation on the Growth Performance of Goats Fed with Urea Treated Rice Straw
}

\author{
Chet Raj Upreti ${ }^{1}$ and Edgar A. Orden ${ }^{2}$ \\ ${ }^{I}$ Nepal Agricultural Research Council \\ Khumaltar, Lalitpur GPO. Box 1950 \\ ${ }^{2}$ Central Luzon State University, Muñoz, Nueva Ecija, Philippines \\ e-mail: crupreti@yahoo.com
}

\begin{abstract}
An experiment was conducted for 90 days to determine the effect of energy level using different levels of RB on the UTRS as a basal diet supplemented with fixed level of Leucaena on growing goats. Experimental diets included four levels of rice bran: $0 \%$ rice bran (RB), $10 \% \mathrm{RB}, 20 \% \mathrm{RB}$, and 30\% RB in basal diets. A total of 20 growing female goats of 5 to 6 months age were randomly allocated into four different dietary groups. Findings showed that inclusion of $20 \%$ rice bran significantly $(\mathrm{P}<0.05)$ improved in total DMI than the other levels. A $30 \%$ RB inclusion was not able to improve further the total DMI, which might be due to the negative effect of higher level of anti-nutritional factor in rice bran. In-situ degradation of $\mathrm{D}_{3}$ and $\mathrm{D}_{4}$ recorded the higher estimated solid outflow rate indicating on the improvement on digestion of feedstuffs. The 20 and $30 \%$ RB inclusion resulted to significantly $(\mathrm{p}<0.05)$ higher OM digestibility of UTRS-based diet with Leucaena supplementation. ADG (41.1g), FCE (10.96) and benefit over feed cost Philippino Peso 238.2) was significantly higher in diet groups with $20 \%$ RB inclusion. Based on the results, it can be concluded that the supplementation of rice bran at $20 \%$ level is economic net income (US\$2.040/goat) in feeding goats with UTRS based diet and supplemented with $20 \%$ of Leucaena.
\end{abstract}

Key words: goat, urea treated rice straw, rice bran, digestibility, growth performance

\section{Introduction}

Rice is the major staple food of the people in Asian countries. About $576 \mathrm{mt}$ of rice straw is produced in Asia (FAO 2000). Nepal annually produces about $4.5 \mathrm{mt}$ of it. Between the crop residue and agro-industrial byproducts, rice straw contributes about $40 \%$. Therefore, the availability of rice straw in the country indicates potentially higher level of feed resource for ruminants. But the use of rice straw as a feed to ruminants is limited due to the low content of $\mathrm{N}$, readily available energy and minerals, which are not adequate to maintain the requirements of the animals. The other problems associated with rice straw are its low digestibility, low intake by ruminant animals higher level of silica and high degree of lignifications (Sahoo 2000). The undegradable lingo-cellulosic complex reduces the availability of fermentable substrate in the ration of the farm animals (Ørskov 2000). Due to these limitations, there is a need to improve the nutritive value of rice straw.

However, even if the nutritive value of the rice straw is improved by urea treatment, it alone cannot supply nutrients beyond the maintenance level (Sharma et al.
1995). To correct the nutritional imbalance of rice straw based diet, supplementation of energy and protein rich concentrate has often been suggested (Umunna et al. 1995). Nevertheless, to avail of the added $\mathrm{N}$ in the form of urea in the straw, supplementation to provide readily available energy to rumen microbes is needed. Rice bran is locally available and a cheap energy source. It supplies energy to the rumen and ensures synchronicity of protein and energy in UTRS based diet for more efficient utilization and microbial protein synthesis. But the higher level affects microbial growth and ultimately affects the nutrient digestibility. Therefore, it is important to find out the suitable level of RB for maximum growth among ruminants.

Leucaena leucocephala is rich in by-pass protein and minerals. It is widely grown in Asian region. It can also be used as a supplement to straw based diet to improve microbial growth and fiber digestion in the rumen of ruminants (Murry et al. 1990). 
Therefore, this study was aimed to determine the effects of different levels of rice bran (RB) as an energy supplement on the utilization of urea treated rice straw (UTRS) supplemented with fixed level of Leucaena on the digestibility and growth performance of upgraded goats. The study was conducted at the Small Ruminant Center, Central Luzon State University, Science City of Muñoz, Nueva Ecija, Philippines from October 2003 to February 2004.

\section{Materials and Methods}

\section{Rice straw treatment}

About $50 \mathrm{~g}$ of fertilizer grade urea $(46 \% \mathrm{~N})$ was dissolved in 91 of water and evenly sprayed on $10 \mathrm{~kg}$ of rice straw providing $23 \mathrm{~g} \mathrm{~N}$ per $\mathrm{kg} \mathrm{DM}$ as suggested by Chenost et al. 1997. The treated rice straw was thoroughly mixed and packed in polyethylene sack. Air was removed from the sack using a vacuum pump to insure anaerobic condition. The sacks were tightly secured with rope and incubated at room temperature of about 20 to $30^{\circ} \mathrm{C}$. After 15 days of curing, the sacks were opened and the straw was spread on the concrete floor to allow drying for $48 \mathrm{~h}$ and ensure evaporation of excess ammonia.

\section{Experimental design diets and animal feeding}

A 90-day trial was conducted using 20 growing goats (50\% Cross of Boar and Philippine native goats) with age ranging from 4-5 months and of similar live weight was randomly distributed into four different treatment groups following a completely randomized design (CRD). A 14-day adjustment period was adopted prior to start of the trial. Longer adjustment period was adopted to ensure the normal consumption of the basal diet (Rymer 2000). Animals were kept in individual pens equipped with feeder and water trough. Animals were drenched against internal parasites seven days before the start of the experiment. Dipping with acaricide was done against external parasites.

Experimental diets were as follows:

Diet $_{1}=$ UTRS ad lib $+20 \%$ Leucaena $+0 \% \mathrm{RB}$

Diet $_{2}=$ UTRS ad lib $+20 \%$ Leucaena $+10 \% \mathrm{RB}$

Diet $_{3}=$ UTRS ad lib $+20 \%$ Leucaena $+20 \% \mathrm{RB}$

Diet $_{4}=\mathrm{UTRS}$ ad lib $+20 \%$ Leucaena $+30 \% \mathrm{RB}$
The animals were offered with rice bran (D1 of $12 \%$ CP) and Leucaena supplemented feed prior to UTRS feeding. Daily feed allowance was given in two equal proportions at 09:00 AM and 05.00 PM.

\section{Digestibility of feedstuff}

The coefficient of digestibility (COD) was calculated using the following formula for each constituent of the dry matter of the feedstuff:

\section{$\mathrm{COD}=\underline{\text { Nutrient consumed }- \text { Nutrient in feces }} \times 100$ Nutrient consumed}

\section{Rumen degradability of feedstuff}

Rumen degradation of feedstuff was determined using four cannulated adult male sheep. Residual DM, CP, and NDF values were fitted to the NEWAY computer program to determine degradation characteristics of the feed samples based on the model of Ørskov 1990 and McDonald (1981). The model describes the degradation curve as:

$$
\begin{aligned}
& \mathrm{P}=\mathrm{a}+\mathrm{b}\left(1-\mathrm{e}^{-\mathrm{ct}}\right) \\
& \mathrm{a}=\text { soluble or highly degradable fraction; } \\
& \mathrm{b}=\text { slowly degradable fraction which disappears } \\
& \text { at a constant fractional rate }(\mathrm{c}) ; \\
& \mathrm{c}=\text { degradation rate (per } \mathrm{h}) ; \text { and } \\
& \mathrm{t}=\text { time }(\mathrm{h})
\end{aligned}
$$

The slowly degradable fraction (b) was reestimated as $\mathrm{B}=(\mathrm{a}+\mathrm{b})-\mathrm{A}$

Where $\mathrm{A}=$ actual soluble fraction (washing loss) as proposed by Ørskov and Ryle (1990)

\section{Data collection}

During the collection period, the feed offered and refused were determined daily and representative samples were also collected and analyzed for DM. Each day, about $200 \mathrm{~g}$ of fresh Leucaena leaves used for feeding were also used for DM determination. The leaves from the tree of 45 days after last harvest were oven dried at $60^{\circ} \mathrm{C}$ for $48 \mathrm{~h}$. The recorded values were used to estimate feed intake. Body weight was taken for two consecutive days at 8.00 AM before feeding. The initial body weight was the average of two consecutive days. The same procedure was adopted to take the final body weight on day 91 in the morning. Initial and final body weight was recorded to determine body weight gain over the experimental period. 
Fortnightly, body weight was taken in the morning before feeding to monitor the trend of weight change.

\section{Cost and benefit analysis}

Partial budget analysis was done to determine the net benefit or loss of using different level of RB in goat diet. Weight gain over the 90-day experimental period and prevailing from the price of chevon of Philippino peso $140 / \mathrm{kg}$ meat was used to calculate the total return. The cost of RB at different levels was computed based on retail price of rice bran at Philippino Peso $21.5 / \mathrm{kg}$. Labor cost of offering the dietary levels was not included in the computation of cost because the difference was relatively low between diets. The following formula was used to calculate the net benefit (loss).

Net benefit (loss) $=$ Added return - Added cost

\section{Chemical analyses}

Representative samples of feeds and refusals were subjected to DM and OM analyses following the AOAC (1990) procedure. Nitrogen content offeed samples was determined using standere procedure. Fiber fractions such as $N D F, A D F$, and $A D L$ were analyzed following the method of Goering and Van Soest (1970).

\section{Statistical analyses}

Analysis of variance was conducted using the General Linear Model (GLM) by Number Crunch Statistical System (NCSS) Version 6.0. Mean comparison was done using Duncan's Multiple Range Test (DMRT).

\section{Results and Discussion}

\section{Chemical composition of feedstuff}

The chemical composition of feedstuff used in the both digestibility and feeding experiments is shown in Table 1. Urea treatment increased the CP content of the UTRS by two folds, indicating that the $\mathrm{N}$ was attached to the fibrous components of the straw. Other workers also reported improvement on the $\mathrm{CP}$ content of poor quality materials ranging from 6.7 to $14 \%$ when ammoniation was practiced (Dolbberg et al. 1981, Kayouli, 1988).

A lower NDF was recorded with UTRS compared with untreated rice straw. The 54\% NDF content of UTRS suggests ideal fiber content of dry roughages (Tanabe 2000). Rice bran contains $12.2 \% \mathrm{CP}$, and 16.38 $\%$ NDF. On the other hand, the CP content of Leucaena was ideally high, $23.56 \%$ and relatively low NDF content (Table 1).

Table 1. Chemical composition of RS, UTRS, Leucaena, and rice bran

\begin{tabular}{|c|c|c|c|c|}
\hline \multirow[t]{2}{*}{ Nutrients } & \multicolumn{4}{|c|}{ Feedstuff } \\
\hline & Rice straw & Rice bran & Leucaena & UTRS \\
\hline Dry matter (\%) & 88.31 & $\begin{array}{l}86.0 \\
\% \text { DM basis }\end{array}$ & 27.4 & 86.0 \\
\hline Organic matter & 78.65 & 88.45 & 89.34 & 83.45 \\
\hline Crude ash & 19.5 & 11.55 & 10.66 & 16.55 \\
\hline Crude protein & 3.8 & 12.2 & 23.56 & 8.2 \\
\hline $\mathrm{NDF}$ & 58.75 & 16.38 & 17.89 & 54.98 \\
\hline ADF & 47.13 & 9.24 & 6.97 & 45.96 \\
\hline Hemicellulose & 11.62 & 7.14 & 10.92 & 9.02 \\
\hline
\end{tabular}

Source: Laboratory analysis at Philippine Carabo Center, Muñoz, Nueva Ecija, 2004.

\section{Voluntary feed intake}

The addition of $20 \%$ and $30 \%$ RB significantly increased the total DM intake but not the straw intake by the goats (Table 2). The beneficial effect of supplementation on enhancing consumption eventually resulted to higher gain among upgraded goats receiving UTRS. Similar result was observed among lambs feeding on more degradable diets brought about by the addition to more digestible feed materials. Ørskov (1990) explained that the beneficial effect of providing greater amount of rumen degradable OM through supplementation could enhance greater microbial activity and fiber degradation that could result to higher intake on goats. 
Nepal Journal of Science and Technology 9 (2008) 29-36

Table 2. Dry matter intake (DMI) of growing goats fed with UTRS, Leucaena and RB

\begin{tabular}{|c|c|c|c|c|c|}
\hline & Diet $_{1}$ & Diet $_{2}$ & Diet $_{3}$ & Diet $_{4}$ & sig level \\
\hline \multicolumn{6}{|l|}{ Dry mater intake (g/day) } \\
\hline Urea treated rice straw & $207.82^{\mathrm{a}}$ & $219.71^{\mathrm{a}}$ & $231.4^{\mathrm{a}}$ & $197.4^{\mathrm{a}}$ & ns \\
\hline Leucaena leaves & $101.41^{\mathrm{a}}$ & $98.2^{\mathrm{a}}$ & $106.0^{\mathrm{a}}$ & $94.1^{\mathrm{a}}$ & ns \\
\hline Rice bran & 0.0 & $51.18^{\mathrm{c}}$ & $106.1^{\mathrm{b}}$ & $135.6^{\mathrm{a}}$ & \\
\hline Total & $309.23^{\mathrm{b}}$ & $369.09^{\mathrm{ab}}$ & $443.50^{\mathrm{a}}$ & $427.15^{\mathrm{a}}$ & $* *$ \\
\hline \multicolumn{6}{|c|}{ Dry mater Intake ( $\left.\mathrm{g} / \mathrm{kg} \mathrm{W}^{0.75}\right)$} \\
\hline Urea treated rice straw & $31.51^{\mathrm{a}}$ & $31.54^{\mathrm{a}}$ & $29.97^{\mathrm{a}}$ & $27.98^{\mathrm{a}}$ & ns \\
\hline Leucaena leaves & $14.00^{\mathrm{a}}$ & $14.08^{b}$ & $13.6^{\mathrm{b}}$ & $13.2^{\mathrm{b}}$ & $*$ \\
\hline Rice bran & 0.0 & $7.42^{\mathrm{c}}$ & $13.65^{\mathrm{b}}$ & $19.14^{\mathrm{a}}$ & $* *$ \\
\hline Total & $46.89^{b}$ & $53.05^{\mathrm{b}}$ & $57.19^{\mathrm{a}}$ & $60.34^{\mathrm{a}}$ & $*$ \\
\hline \multicolumn{6}{|c|}{ Dry mater intake (\% of BW) } \\
\hline Urea treated rice straw & $1.664^{\mathrm{a}}$ & $1.660^{\mathrm{a}}$ & $1.520^{\mathrm{a}}$ & $1.414^{\mathrm{a}}$ & $\mathrm{ns}$ \\
\hline Total & $2.472^{\mathrm{b}}$ & $2.788^{\mathrm{ab}}$ & $2.894^{\mathrm{a}}$ & $3.094^{\mathrm{a}}$ & $* *$ \\
\hline
\end{tabular}

Means with common superscripts within rows are not significantly different.

Level of significance, $\mathrm{ns}=$ not significant $(\mathrm{P}<0.05) ; * \mathrm{P},<0.05 ; * * \mathrm{P}<0.001)$

Table 3. Type of feed and nutrient intake by growing goats in different treatment groups

\begin{tabular}{|c|c|c|c|c|c|c|}
\hline \multirow[t]{2}{*}{ Diets } & \multirow[t]{2}{*}{ Feeds } & \multicolumn{4}{|c|}{ Nutrient intake (g/day) } & \multirow[b]{2}{*}{ HEMI } \\
\hline & & DM & $\mathrm{CP}$ & NDF & ADF & \\
\hline \multirow[t]{4}{*}{ Diet 1} & UTRS & 207.8 & 17.04 & 114.25 & 95.51 & 18.74 \\
\hline & Leucaena & 101.43 & 23.89 & 18.15 & 7.07 & 11.08 \\
\hline & Rice bran & 0.0 & 0.0 & 0.0 & 0.0 & 0.0 \\
\hline & Total intake & 309.23 & 40.93 & 132.40 & 102.56 & 29.82 \\
\hline \multirow[t]{4}{*}{ Diet 2} & UTRS & 219.71 & 18.01 & 120.79 & 100.98 & 19.82 \\
\hline & Leucaena & 98.15 & 23.12 & 17.56 & 6.84 & 10.72 \\
\hline & Rice bran & 51.18 & 6.24 & 8.38 & 4.73 & 3.65 \\
\hline & Total intake & 369.04 & 47.37 & 146.74 & 112.55 & 34.19 \\
\hline \multirow[t]{4}{*}{ Diet 3} & UTRS & 231.37 & 18.97 & 127.21 & 106.34 & 20.87 \\
\hline & Leucaena & 105.88 & 24.94 & 18.94 & 7.38 & 11.56 \\
\hline & Rice bran & 106.08 & 12.93 & 17.37 & 9.80 & 7.57 \\
\hline & Total & 443.33 & 56.84 & 163.52 & 123.52 & 40.0 \\
\hline \multirow[t]{4}{*}{ Diet 4} & UTRS & 197.49 & 16.19 & 108.58 & 90.77 & 17.81 \\
\hline & Leucaena & 94.07 & 22.16 & 16.83 & 6.56 & 10.27 \\
\hline & Rice bran & 135.59 & 16.54 & 22.21 & 12.53 & 9.68 \\
\hline & Total intake & 428.15 & 54.89 & 147.62 & 109.85 & 37.77 \\
\hline \multirow[t]{4}{*}{$\begin{array}{l}\text { Degradationc } \\
\text { (fraction } / \mathrm{h})\end{array}$} & RS & 0.018 & 0.04 & 0.017 & 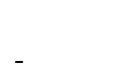 & - \\
\hline & UTRS & 0.028 & 0.023 & 0.025 & - & - \\
\hline & Leucaena & 0.074 & 0.056 & 0.047 & - & - \\
\hline & Rice bran & 0.10 & 0.081 & 0.076 & - & - \\
\hline
\end{tabular}




\section{R. Upreti \& Edgar A. Orden/Effect of Rice Bran and Leucaena........}

Another contributory factor that could have triggered higher consumption in the $\mathrm{D}_{3}$ and $\mathrm{D}_{4}$ is the higher estimated solid outflow rate of the rumen digesta from the In-situ degradation data (Table 3). Results support the conclusion of Zhao et al. (1996) that one of the major effects by-product feed supplementation is increase outflow rate, with the concomitant reduction in gut retention time (MRT) and eventually leading to greater consumption. Hence, the relatively low intake among animals receiving $\mathrm{D}_{1}$ and $\mathrm{D}_{2}$ emphasizes the need for supplemental energy that will match the highly soluble nitrogen from UTRS to encourage adequate consumption.

\section{Nutrient digestibility}

Table 4 presents the in vivo nutrient digestibility and digestible nutrient intake of growing upgraded goats fed with UTRS-based diets supplemented with different level of RB. The 20 and $30 \% \mathrm{RB}$ inclusion resulted to significantly higher $(\mathrm{p}<0.05)$ OM digestibility of UTRSbased diet with Leucaena supplementation. Moreover, the increasing levels of RB supplementation resulted to an increasing OM digestibility, reaching $85 \%$ at $30 \%$ supplementation rate. This could be attributed to the readily-soluble carbohydrates from $\mathrm{RB}$ needed by microbes to enhance rumen activity (Palamquist \& Jenkins). Digestibility in the rumen is a function of the fermented matter and microbial growth rates thus, with more soluble sugar in the UTRS- based diet, overall digestibility is increased.

Table 4. Dry matter (DM) intake, in vivo digestibility and digestible nutrient intake of goats fed with UTRS based diet supplemented with Leucaena and different level of RB

\begin{tabular}{|c|c|c|c|c|c|}
\hline Nutrient & Diet1 & Diet2 & Diet3 & Diet4 & SigLevel \\
\hline \multicolumn{6}{|c|}{ Nutrient Digestibility (\%) } \\
\hline DM & 50.57 & 51.18 & 52.56 & 53.11 & Ns \\
\hline $\mathrm{OM}$ & $81.42^{\mathrm{b}}$ & $81.67^{\mathrm{b}}$ & $82.79^{\mathrm{a}}$ & $85.74^{\mathrm{a}}$ & $* *$ \\
\hline $\mathrm{CP}$ & 46.93 & 47.212 & 47.25 & 48.82 & ns \\
\hline NDF & 34.02 & 29.92 & 42.66 & 39.47 & ns \\
\hline \multicolumn{6}{|c|}{ Digestible Nutrient Intake (g/ kg W ${ }^{0.75}$ ) } \\
\hline DM & $24.41^{b}$ & $26.20^{\mathrm{ab}}$ & $30.82^{a b}$ & $32.02^{\mathrm{a}}$ & $*$ \\
\hline $\mathrm{OM}$ & 19.60 & 17.15 & 18.57 & 16.04 & $\mathrm{~ns}$ \\
\hline $\mathrm{CP}$ & 3.35 & 3.04 & 3.48 & 3.80 & ns \\
\hline NDF & 7.24 & 6.03 & 9.26 & 7.88 & ns \\
\hline
\end{tabular}

Mean with common superscripts within rows are not significantly different.

Level of significance, $\mathrm{ns}=$ not significant $(\mathrm{P}<0.05) ; * * \mathrm{P},<0.01$

On the other hand, RB supplementation did not result to positive increase in $\mathrm{CP}$ and NDF digestibility. Although, the 47 to $49 \% \mathrm{CP}$ digestibility in $\mathrm{D}_{3}$ and $\mathrm{D}_{4}$ respectively were not significantly better than $\mathrm{D}_{1}$ and $\mathrm{D}_{2}$. Results tend to support the conclusion of Males (1987) where he reported that about 50\% N from UTRS -based diets are available for digestion. The relatively low CP digestibility in $\mathrm{D}_{1}$ suggests the need of energy supplementation to the UTRS-based diet in order to increase $\mathrm{N}$ availability to correct certain nutrient deficiencies.

Fiber digestibility was not affected by RB supplementation. The negative effect of higher levels of soluble carbohydrate supplementation on NDF digestibility was not observed in this study, contrary to the findings of Chowdhury (1997) where he reported that a RB level of more than $30 \%$, reduced cell wall digestibility when fed to cattle. Likewise, Mgheni et al. (1993) earlier reported that the finding of UTRS and RB (70:30) could provide optimum rumen environment for straw degradation without necessarily affecting cell wall digestibility.

\section{Effect on growth performance and feed conversion efficiency}

The effects of different levels of RB on ADG and FCE of goats fed with UTRS + Leucaena is shown in Table 5 and Figure 1. Significantly higher $(\mathrm{p}<0.05)$ ADG of $41.11 \mathrm{~g}$ was recorded with $20 \% \mathrm{RB}$ supplementation. The poor performance of animals fed solely with UTRS is manifested by their lowest growth rate of $7 \mathrm{~g}$ indicating serious lack of energy provided by the diet. As pointed out earlier, consumption of $\mathrm{D}_{1}$ was not even enough to 
support protein and energy requirement at maintenance level. With higher levels of RB inclusion, it ensured greater amount of degradable OM incorporation in UTRS + Leucaena diets that elicited more intake and ultimately resulted to better ( $\mathrm{p}<0.05$ ) ADG beyond $20 \%$ level. This could have been due to the supplemental energy from RB that increased the proportion of easily available carbohydrates for better microbial rumen activity as suggested by Zhao et al. (1996). Chowdhury (1997) also observed that a higher level of RB than $30 \%$ of the diet is responsible in increasing milk yield in dairy cattle fed with cereal straw diet.
Moreover, FCE was significantly higher $(\mathrm{p}<0.01)$ with higher RB supplementation. The result indicated that FCE could not be increased without concentrate supplementation with UTRS as basal diet among growing upgraded goats. This was first demonstrated by Mgheni et al. (1993) where they recorded very low FCE of $91.40 \mathrm{~g} \mathrm{DM} / \mathrm{kg}$ gain among sheep fed ad libitum with pure UTRS diet. With greater DM intake in D3 and $\mathrm{D}_{4}$, more efficient feed utilization was recorded and consequently producing bigger and heavier animals at the end of the trial. Likewise, the higher digestibility of OM brought about by RB supplementation could have contributed to improvement of the overall feeding value of the diet.

Table 5. Live weight, growth performance, and feed conversion efficiency of growing goats fed with UTRS, Leucaena and different levels of RB

\begin{tabular}{llllll}
\hline & Diet $_{1}$ & Diet $_{2}$ & Diet $_{3}$ & Diet $_{4}$ & Sig level \\
\hline Live weight $(\mathrm{kg})$ & & & & & $\mathrm{ns}$ \\
Initial & 11.83 & 11.44 & 11.75 & 10.7 & $* *$ \\
Final & $12.46^{\mathrm{d}}$ & $13.4^{\mathrm{c}}$ & $15.45^{\mathrm{a}}$ & $14.1^{\mathrm{b}}$ & $* *$ \\
Average daily gain (g/d) & $7.0^{\mathrm{d}}$ & $21.77^{\mathrm{c}}$ & $41.11^{\mathrm{a}}$ & $37.77^{\mathrm{a}}$ & $*$ \\
Feed conversion efficiency (FCE) & $53.22^{\mathrm{a}}$ & $18.56^{\mathrm{b}}$ & $10.96^{\mathrm{d}}$ & $11.30^{\mathrm{c}}$ & $*$ \\
\hline
\end{tabular}

Feed conversion efficiency calculated as gram total DMI per gram live weight gain per day.

Means with common superscripts within rows are not significantly different.

Level of significance, ns not significant, $* \mathrm{P}<0.05$

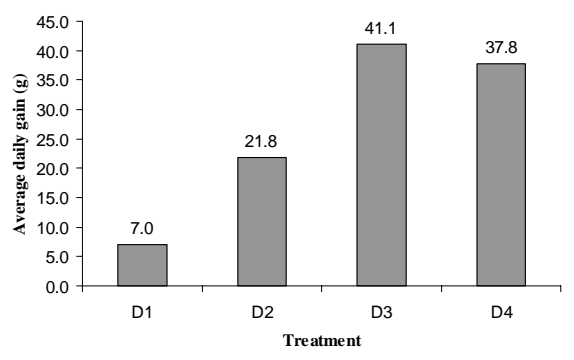

Figure 1. Average daily weight gain of growing goats

\section{Cost and benefit analysis of rice bran supplementation}

Table 6 and 7 present the cost and return, and benefit/loss of feeding different levels of UTRS to upgraded goats. The feeding of $20 \%$ RB to UTRS + Leucaena generated more return, amounting to US\$2.040 compared with the other dietary treatments. However, increasing the RB inclusion to $30 \%$ did not result to further increase in net benefit, but rather could lead to net loss of US\$ 0.875. The higher income or benefit realized in D3 is attributable to the heavier animals after the feeding trial. Result suggests that the most economical level of RB supplementation in UTRS based diet is $20 \% \mathrm{RB}$.

Table 6. Summary of cost and return in growing upgraded goats fed with UTRS based diet supplemented with different level of RB (Philippino Peso/ head)

\begin{tabular}{|c|c|c|c|c|c|}
\hline Parameters & Diet $_{1}$ & Diet $_{2}$ & Diet $_{3}$ & Diet $_{4}$ & Level of sig. \\
\hline Gain in dress meat (kg) & $0.378^{\mathrm{a}}$ & $1.176^{\mathrm{b}}$ & $2.22^{\mathrm{c}}$ & $2.04^{\mathrm{c}}$ & $*$ \\
\hline Marginal return (US\$) & $1.005^{\mathrm{a}}$ & $3.128^{b}$ & $5.905^{\mathrm{c}}$ & $5.426^{\mathrm{d}}$ & $*$ \\
\hline Cost of rice bran & $0.0^{\mathrm{a}}$ & $0.686^{\mathrm{b}}$ & $1.423^{\mathrm{c}}$ & $1.819^{\mathrm{d}}$ & $*$ \\
\hline Net benefit & $1.005^{\mathrm{a}}$ & $2.442^{b}$ & $4.482^{c}$ & $3.607 \mathrm{~d}$ & $*$ \\
\hline
\end{tabular}

Means with common letters superscript are not significantly different $(\mathrm{P}<0.05)$ Level of significance, $* \mathrm{P}<0.05$ ) 


\section{R. Upreti \& Edgar A. Orden/Effect of Rice Bran and Leucaena........}

Table 7. Summary of the net benefit or loss between diets of growing upgraded goats (US\$/ head)

\begin{tabular}{llll}
\hline Parameters & Diet $_{2}$ vs Diet $_{1}$ & Diet $_{3}$ vs Diet $_{2}$ & Diet $_{4}$ vs Diet $_{3}$ \\
\hline Added return & 111.72 & 146.16 & 0.0 \\
Added cost & 36.11 & 38.77 & 46.05 \\
Net benefit (Loss)(US\$) & 1.437 & 2.040 & 0.875 \\
\hline
\end{tabular}

In conclusion, the inclusion of $20 \% \mathrm{RB}$ increased total DM intake and OM digestibility of UTRS-based diet that resulted to improved ADG and FCE among upgrades goats. Growth performance revealed that $20 \%$ RB inclusion to UTRS produced heavier animals after 90 days feeding. Although there was no significant increase in straw intake and fiber digestibility, the overall quality of the diet was improved with RB supplementation. Moreover, higher income which amounted to US\$2.040 per animal was realized due to heavier animals at market weight when fed with UTRS supplemented with $20 \% \mathrm{RB}$ and Leucaena.

In order to produce bigger and heavier animals at market, 20\% RB supplementation is recommended for growing upgraded goats fed with UTRS-based diet + Leucaena. More efficient feed utilization can also be realized with the inclusion of more degradable $\mathrm{OM}$ from RB supplementation, essential in maintaining desirable rumen environment that will ensure optimum intake. Thus, higher productivity and more profitable goat enterprise can be attained with the extensive utilization of cheap and locally abundant feed resources.

\section{Acknowledgement}

The authors would like to thank AREP, a world bank funded project in Nepal, for funding this study. They are also grateful to all the staff of Central Luzon State University, Muñoz, Nueva Ecija, Philippines who helped us to conduct the experiment. Dr. S.M. Pradhan is thankful for his help during the study. We would like to thank Prof.Dr. F.P. Neupane and Professor Dr. M.P. Sapkota for editing the text.

\section{References}

AOAC. 1990. Official methods of analysis. (15 th ed). Association of Official Analytical Chemists, Washington, DC.

Chenost, M. and C. Kayouli. 1997. Roughages utilization in warm climates. FAO 135: 1-225.

Chodhury, S.A. 1997. Effect of graded levels of rice mill feed supplementation on intake, nutrient digestibility and microbial $\mathrm{N}$ yield and growth rate of native (Bos indicus) bulls fed rice straw alone. Asian-Aus. J. Anim. Aci. 10: 445-454.

Dolberg, F., M. Saadullah, M. Haque and R. Haque. 1981. Storage of urea treated straw using indigenous materials. World Animal Review 38:37-41.

FAO 2000. Production Yearbook 2000. FAO, Rome, Itali.

Kayouli, C. 1988. Traitement a l'uree des fourrrages grossiers en milieu agricole, Report de mission. FAO du Project TCP/NER/6758.

Males, J. R. 1987. Optimizing the utilization of cereal crop residue for beef cattle. J. Anim. Sci. 65: 1124-1130.

McDonald, I. 1981. A revised model for the estimation of protein degradability in the rumen. J. Agric. Sci. Camb. 96: 251-252.

Mgheni , D. M., A. E. Khimambo, F. Sunstol and J. Madsen. 1993. Influence of urea treatment or supplementation on degradation, intake or growth performance of goats fed rice straw diets. Anim. Feed Sci. Technol. 44: 209-220.

Murry, R. J., A. B. McAllan and R. H. Smith. 1990. In vitro continuous culture studies on the effect on nitrogen source of rumen microbial growth and fiber digestion. Anim. Feed Sci. Technol. 31:55-64.

Ørskov, E. R. and M. Ryle 1990. Energy nutrition in ruminants. Elsevier Applied Sci., London. pp 1-5.

Ørskov, E. R. 2000. The in situ technique for the estimation of forage degradability in ruminant. Center for Animal Breeding International. pp. 30-32.

Ørskov, E. R., 1990. Energy nutrition in ruminants. Elsevier Applied Sci. London. pp. 214-217.

Rymer, C. 2000. The measurement of the forage digestibility in vivo. In: Forage available in ruminant nutrition. $C A B$ international. pp. 113-134.

Sahoo, A., L. C. Chaudhary, N. Agrawal, D. N. Kumar, and N.N. Pathak. 2000. Effect of feeding different ratio of grass fodder and straw supplemented with wheat bran on the performance of male crossbred calf. Asian Aust. J. Anm. Sci. 13 (1): 19-22. 
Nepal Journal of Science and Technology 9 (2008) 29-36

Sharma, D. D., D. V. Rangnekar and M. Singh. 1995. Physical and chemical treatment of fibrous crop residue to inprove nutritive value. In: A review on fibrous crop residues. NDRI, India. pp. 263-276.

Tanabe, S. 2000. Quality criteria offeed. Technical manual for feed analysis. Japan Livestock Technology Association. Japan. pp. 73-76.

Umunna, N. N., P. O. Osuji, H. Khalili, I. V. Nsahlai and S. Crosses. 1995. Comparative feeding value of forage from two cereal legumes based cropping system for beef production from cross bred (Bos taurus $\mathrm{x}$ Bos indicus) streer and subsequent performance of underfed and realimented streer. Animal Science 61: 35-45.

Zhao, Y., K. Taniguchi and T. Obitsu. 1996. Effect of by-product diets containing rice bran and beet pulp on the site and extent of digestion and microbial synthesis in deer. Asian-Aust. J. Anim. Sci. 10: 215-222. 